\title{
FLOW CHARACTERIZATION IN THE SANTEE CAVE SYSTEM IN THE CHAPEL BRANCH CREEK WATERSHED, UPPER COASTAL PLAIN OF SOUTH CAROLINA, USA
}

\author{
Amy E. Edwards ${ }^{1}$, Devendra M. Amatya², Thomas M. Williams³, Daniel R. Hitchcock ${ }^{3}$, And
} APRIL L. JAMES ${ }^{4}$

\begin{abstract}
Karst watersheds possess both diffuse and conduit flow and varying degrees of connectivity between surface and groundwater over spatial scales that result in complex hydrology and contaminant transport processes. The flow regime and surfacegroundwater connection must be properly identified and characterized to improve management in karst watersheds with impaired water bodies, such as the Chapel Branch Creek (CBC), South Carolina watershed, which has a long-term sampling station presently listed on an EPA 303(d) list for phosphorous, $\mathrm{pH}$, and nitrogen. Water from the carbonate limestone aquifer of the Santee Cave system and spring seeps in the CBC watershed were monitored to characterize dominant flow type and surface-groundwater connection by measuring dissolved calcium and magnesium, total suspended solids, volatile suspended solids, alkalinity, $\mathrm{pH}$, specific conductance, and stable isotopes $\left(\delta^{18} \mathrm{O}\right.$, $\left.\delta^{2} \mathrm{H}\right)$. These measurements indicated that the conduit flow to Santee Cave spring was recharged predominantly from diffuse flow, with a slow response of surface water infiltration to the conduit. Qualitative dye traces and stage elevation at Santee Cave spring and the adjacent Lake Marion (equal to the elevation of the flooded portion of $\mathrm{CBC}$ ) also indicated a relation between fluctuating base level of the $\mathrm{CBC}$ reservoir-like embayment and elevation of the Santee Limestone karst aquifer at the spring. Methods described herein to characterize the flow type and surface-groundwater connection in the Santee Cave system can be applied not only to watershed management in the Chapel Branch Creek watershed, but also to the greater region where this carbonate limestone aquifer exists.
\end{abstract}

\section{INTRODUCTION}

This study uses measurements of dissolved calcium and magnesium, total suspended solids, volatile suspended solids, alkalinity, $\mathrm{pH}$, specific conductance, stable isotopes $\left(\delta^{18} \mathrm{O}\right.$, $\delta^{2} \mathrm{H}$ ), dye tracing, and stage elevation measurements from both the Santee Cave spring and Lake Marion to characterize the flow regime and surface-groundwater connection in the Santee Limestone (SL) aquifer in the Chapel Branch Creek (CBC) watershed in South Carolina. The hydrology and water quality of the $\mathrm{CBC}$ watershed is significantly impacted by its karst terrain and the shallow carbonate aquifer of the regional SL formation. The karst terrain provides a potential for rapid and substantial loss of surface water to the groundwater in the aquifer. The anisotropic porosity of the carbonate bedrock, created by bedding planes, fractures, and ongoing dissolution within the matrix of the carbonate rock, produces groundwater movement from zones of recharge to discharge through a network of voids of diverse sizes and various degrees of vertical and horizontal connectivity. The result is a watershed dominated by subsurface flow, in which surface water is commonly lost to the subsurface, and groundwater is stored or discharged via springs to $\mathrm{CBC}$ at different rates and flow regimes throughout the aquifer (Williams et al., 2012).
The two main types of flow applied to karst aquifers are diffuse and conduit (Shuster and White, 1971; Atkinson, 1977; Gunn, 1986), also referred in the literature as slow and fast flow, respectively. Diffuse flow occurs when the voids in the aquifer matrix are poorly connected and typically result in a system with slow groundwater movement and longer periods of water storage (Fiorillo, 2009). Conduit flow results when voids in the aquifer become well developed and possess high connectivity, thus having less water storage and a more rapid response of recharge to discharge (Fiorillo, 2009). Atkinson (1977) concluded that most flow in karst aquifers occurs in conduits, whereas most water is stored in the matrix. A study by Worthington et al. (2000) analyzed spring and well data from limestone and dolostone aquifers and found that $96 \%$ of storage occurred in matrix, while $94 \%$ of flow occurred in conduits. The SL unit, in the CBC watershed, is

\footnotetext{
${ }^{1}$ Florida A\&M University, School of the Environment, Tallahassee, FL, 32301, USA, amy.edwards@famu.edu

${ }^{2}$ USDA Forest Service, Center for Forested Wetlands Research, Cordesville, SC, 29434, USA, damatya@fs.fed.us

${ }^{3}$ Belle W. Baruch Institute of Coastal Ecology and Forest Science, Clemson University, Georgetown, SC, 29442, USA, tmwllms@clemson.edu dhitchc@clemson. edu

${ }^{4}$ Department of Geography, Nipissing University, North Bay, ON, P1B 8L7, Canada, aprilj@nipissingu.ca
} 
the northern portion of the Floridan aquifer. Several studies of the Floridan aquifer including the southern part of the Floridan aquifer in Florida found spring discharge as primarily diffuse recharge from aquifer matrix (Martin and Gordon, 2000; Martin and Dean, 2001; Katz, 2004; Florea and Vacher, 2006; Moore et al., 2009; Ritorto et al., 2009). Even in conduit dominated systems of the Floridan aquifer, the matrix contributes heavily to aquifer discharge (Moore et al., 2009).

Geochemical and isotopic data from springs have been used in numerous studies in different karst regions to characterize flow in carbonate aquifers and degree of surface-groundwater connections (e.g. Jakucs, 1959; Ashton, 1966; Shuster and White, 1971; Jacobson and Langmuir, 1974; Atkinson, 1977). The discharge from springs represents a composite of all the upbasin waters in an aquifer, which show variations in hydrology and water chemistry depending on contributions from diffuse and conduit flow components (White, 2003). Springs dominated by diffuse flow recharge have fewer variations in flow and water chemistry (Shuster and White, 1971). The water is typically saturated with dissolved ions (e.g. calcium and magnesium), because diffuse flow has longer residence time in the aquifer; and therefore, longer contact with the bedrock (White, 1988). In contrast, systems dominated by conduit flow respond more quickly to aquifer recharge and produce greater variations in spring water chemistry (Shuster and White, 1971; White, 1988). This more rapid infiltration and transit of recharge waters also leaves conduit springs under-saturated (White, 1998), and high suspended solids at springs indicate arrival of surface waters coming from sinkholes and direct surface recharge (Mahler and Lynch, 1999; Massei et al., 2002; Vesper and White, 2004). Stable isotopic analysis is commonly employed to infer the flowpaths and sources of spring waters by using endmember mixing analysis (Katz et al., 1997; Plummer et al., 1998; Criss et al., 2000).

Dye tracing is an established method used to determine connections between recharge and discharge areas in karst aquifers and was used in this study to obtain information about the response of the SL aquifer at the Santee Cave system during times of low and high lake elevations.

The flow type and surface-groundwater connections in the SL carbonate aquifer are clearly important factors in water movement; and thus, also contaminant transport and water quality of the $\mathrm{CBC}$ watershed. The goal of this study is to characterize flow in the watershed using hydrologic, water chemistry, dye tracer, and stable isotope data collected in the Santee Cave system and nearby spring seeps during 2008-2009. The specific objectives of this study are to test two hypotheses: (1) the discharge from SL to $\mathrm{CBC}$ is predominantly a diffuse flow component from the matrix with slow surface-groundwater connection and (2) the aquifer water table at Santee Cave is influenced by stage elevations of the lower flooded portion of CBC.

\section{Site Description}

The region, south of Lake Marion, SC is underlain by the Santee Limestone (SL), a middle Eocene (40 ma), microfossiliferous lime mudstone to slightly shelly wackestone (Willoughby, 2002). The SL is blanketed by the Upper Duplin Formation, a combination of clay and quartz pebble beds, with sinkhole, modern alluvium and swamp deposits throughout the region (Willoughby, 2002). The SL is part of the northern end of the multi-state Floridan aquifer system and a major groundwater aquifer in coastal South Carolina for industrial, agricultural, and public purposes (Hockensmith, 2009). Recharge to SL is by precipitation and surface runoff that infiltrates into the subsurface voids via soil and karst topography (e.g. sinkholes, disappearing streams) and discharges via springs like the Santee Cave spring in Santee, SC along the CBC and the southern shore of Lake Marion. Tritium and radiocarbon dating from a spring northwest of the $\mathrm{CBC}$ watershed and from regional wells for a SC Department of Health and Environmental Control (DHEC) recharge and aquifer vulnerability study found that groundwater was a combination of younger waters from recharge along the southern shore of Lake Marion and older waters from lateral flow from aquifer up dip areas, such as the city of Orangeburg, SC (Stone, per. comm., 2009).

The surface watershed for Chapel Branch Creek is 1,555 hectare $(3,840$ acres) and comprises multiple land uses. The Santee Cave system lies in the forested Santee State Park in the lower part of the watershed. The upper watershed land uses are crop agriculture, roadways and the major interstate I-95, a commercial strip off the I-95 exit, low and medium-density residential areas, two golf courses, and forest. The surface soils in the $\mathrm{CBC}$ watershed are sand or sandy loam and vary from sand to clay in the subsurface (SCS, 1988). The upper watershed is relatively flat and around $36.6 \mathrm{~m}(120 \mathrm{ft})$ above mean sea level (a.m.s.l.), while the lower watershed at the edges of CBC and Lake Marion have steeper topography of around $25.9 \mathrm{~m}(85 \mathrm{ft})$ a.m.s.l.

The CBC watershed drains directly to Lake Marion (Fig. 1). Lake Marion and a lower portion of the CBC are shallow reservoirs created when the Santee River was dammed by the Corps of Engineers for production of hydroelectric power in 1941. The CBC was a spring-fed surface stream before construction of the dam, but afterwards, the lower section became a part of the Lake Marion reservoir. A stretch of the uppermost surface reach of CBC was dammed in 1989 (ERC, 1999) to create a pond for a golf course that releases water downstream by an overflow culvert at location SL7 (Fig. 1). Water from the culvert flows in a channel and remains surface water until it becomes a disappearing stream where it enters the Santee Cave system at a point labeled SS (surface stream) in Figures 1 and 2. During periods of heavy rainfall, the surface water exceeds the capacity of the SS conduit and a 


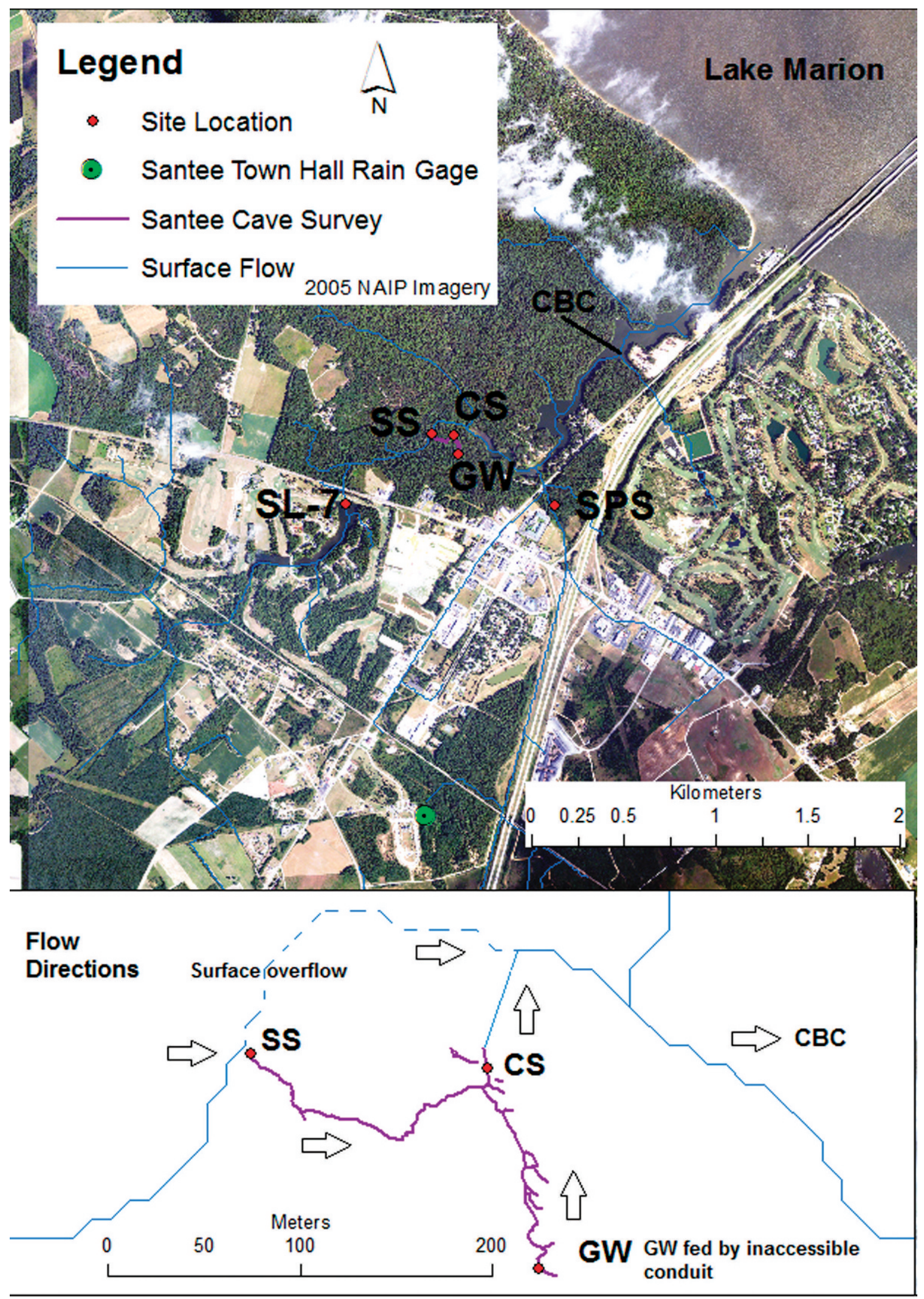

Figure 1. Generalized flow directions for the study site sampling locations in the Chapel Branch Creek watershed. 


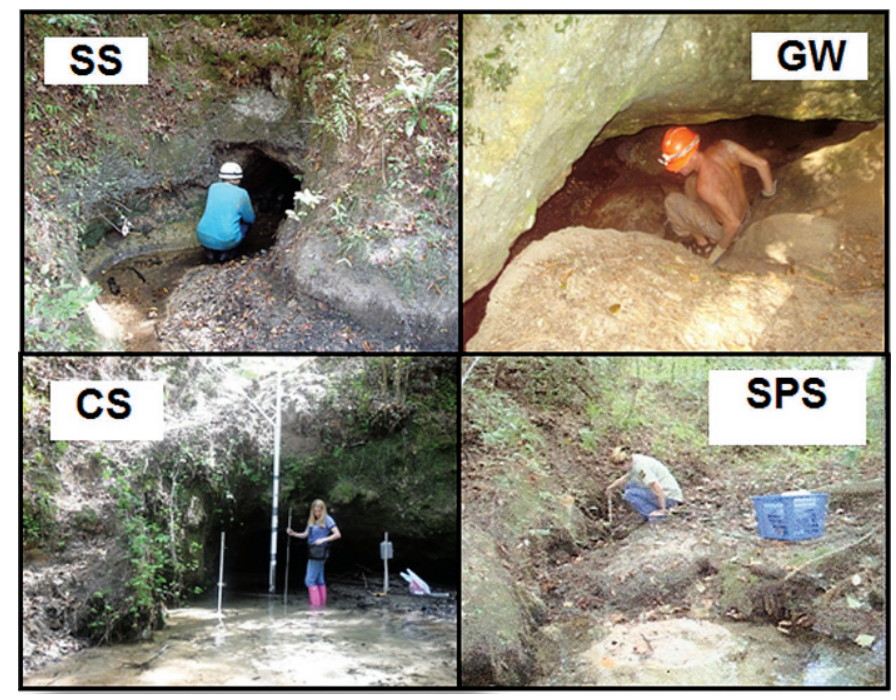

Figure 2. Images of sampling locations SS, GW, CS, and SPS, providing typical conduit pattern and relative scale. Researchers provide scale for these karst features.

portion of flow continues as surface water via a by-pass channel (seen as dashed blue line in Figure 1) to combine with CS (Santee Cave spring) discharge about $175 \mathrm{~m}$ downstream. The flow then enters the lower section of CBC, a shallow water body shown in 2009 bathymetry data to have an average width of 200 meters and depth of 3 meters (Amatya et al., 2011).

The Santee Cave system is a stream passage cave with approximately 300 meters of surveyed passage (Holler, 2000). The flow at CS occurs after the convergence of two main stream passages, one originating at $\mathrm{GW}$ and the other at SS (Figs. 1 and 2). Based on the cave survey map, the stream passage starting at the SS location drops $3 \mathrm{~m}$ (10 feet) along the passage to CS. The GW passage is steeper, dropping $6 \mathrm{~m}$ (20 feet) to CS. These two passages combine before emerging at CS at $26 \mathrm{~m}$ ( 85 feet) MSL. The SS location was sampled where the surface stream disappears into the cave. The GW location was sampled where the groundwater conduit emerges at the bottom of a sinkhole. The inaccessible upstream conduit passage feeding GW most likely continues in a southeastern direction, in line with a 2009 sinkhole collapse, a sinkhole pond, and two other sinkholes detected in LiDAR images (Edwards and Amatya, 2009; 2010). A karst window between GW and CS exposes the cave stream and the cave system lies within a forested nature preserve managed by the South Carolina Department of Natural Resources.

Several small spring seeps (SPS) (Figs. 1 and 2) around $30 \mathrm{~mm}$ diameter at higher elevations than CS, and not connected to the Santee Cave system, were not monitored for flow, but were sampled in August 2009 for dissolved calcium and magnesium, $\mathrm{pH}$, alkalinity, and specific conductance for comparison to GW, CS, and SS. Several of the higher elevation seeps dried up during a period of low precipitation and low lake levels in 2009 (Amatya et al., 2011).

Although water is discharged from the SL aquifer into the $\mathrm{CBC}$ at numerous small springs along the shoreline, the only spring above the shoreline with substantial flow is CS. A water budget using rainfall data from the watershed and flow data at CS indicated that the source of CS discharge is not solely accounted for by runoff collected by the upstream surface-defined watershed, but also includes groundwater contributions from a larger subsurface watershed (Williams et al., 2012). The estimated baseflow for the region, using data collected at CS, is $0.09 \mathrm{~m}^{3} / \mathrm{s}$ (90 1/s). Using these data with a reference value of $2.3 \mathrm{~L} /$ $\left(\mathrm{s} / \mathrm{km}^{2}\right)$ assumed from the method by Quinlan and Ray (1995), the approximate subsurface drainage area for CS is $39.1 \mathrm{~km}^{2}$. This water budget-based calculated area is $\sim 3.5$ times the surface drainage area of $10.9 \mathrm{~km}^{2}$ (1090 ha) delineated at the CS location in the CBC watershed study. This result was plausible given that surface and subsurface watersheds often do not overlap in karst watersheds (White, 1988). This conclusion was further substantiated by the results from hydrologic computer modeling for the CBC watershed study, in which modeling results predicted more surface flow at $\mathrm{CBC}$ subwatershed outlet monitoring stations than measured (Amatya et al., 2011). This "missing" flow at the subwatershed outlets was assumed to be lost from the surface to the groundwater aquifer matrix, eventually discharging downstream into the $\mathrm{CBC}$ via CS or other springs (Williams et al., 2012). Also during the watershed study, flow at CS was found to be yielded predominantly by the GW contribution, with peak flows in the hydrograph occurring from rain events due to influx of surface water from the disappearing stream at SS (Williams et al., 2012). A water balance approach indicated flow from the GW passage to CS was nearly continuous at $0.08 \mathrm{~m}^{3} / \mathrm{s}$; over $60 \%$ of the flow, nearly $50 \%$ of TP loading, and over $70 \%$ of total nitrogen loading into the $\mathrm{CBC}$ reservoir (Williams et al., 2012).

These hydrologic measurements from the watershed study indicate a dominant subsurface source in the CS discharge and likely other springs discharging into the $\mathrm{CBC}$. The nature of this complex watershed hydrology, combined with the karst topography and multiple land uses, make this watershed susceptible to water quality impairment. A long-term sampling station in the CBC has been on the U.S. EPA 303(d) list for impaired water bodies for various combinations of parameters for years, and is presently listed for phosphorous, $\mathrm{pH}$ and nitrogen. Past incidences of pollution include a waste lagoon at a sewage treatment plant in the $\mathrm{CBC}$ surface watershed that disappeared overnight in the 1990s, and the fumigant EDB found in discharge from a spring outside the CBC surface watershed (Stone, per. comm., 2009). Considering this past and ongoing water quality impairment, characterizing the carbonate aquifer for flow type and surfacegroundwater connectivity is relevant for improving water 
Flow characterization in the Santee Cave system in the Chapel Branch Creek watershed, upper coastal plain of South CARolina, USA

quality in the $\mathrm{CBC}$ watershed and the region south of Lake Marion.

\section{Site Monitoring}

\section{Dye Traces}

Three qualitative dye traces based on visual inspection were conducted in the Santee Cave system. The first two traces were carried out on August 28, 2008. A 16 FL. OZ. bottle of Bright Dyes Liquid Concentrate Fluorescent Red was injected into the disappearing stream at location SS, and a 16 FL.OZ. bottle of Bright Dyes Liquid Concentrate Fluorescent Green/Yellow was injected at location GW. Arrival time from GW and SS locations to location at CS (Fig. 1) and the predicted flow path according to the cave survey were recorded. Since a visible amount of organics enters the disappearing stream, and red dye reacts with organics to decompose, a third trace was conducted on April 2, 2009 at location SS using a 16 FL. OZ. bottle of Bright Dyes Liquid Concentrate Fluorescent Green/Yellow dye.

\section{Hydrologic Data}

Stage data at CS were collected using an Infinities Water Level Data Logger at 15-minute intervals. Procedures for detailed instrument calibration, data collection and calculations are found in Amatya et al. (2010). The elevation of the CS water level was determined by adding the stage in feet measured for stage discharge relationship to the cave survey elevation for comparison with Lake Marion elevation, which was used as a proxy for CBC elevation. Lake Marion maximum elevation data (datum NGVD1927) was obtained from USGS gaging station \#02169921 at Lake Marion near Elloree, SC (USGS, 2009).

\section{Water Quality and Isotope Sampling and Analysis}

Water quality measurements were taken on a predominantly monthly basis during various flow conditions. Measurements for $\mathrm{pH}$ and specific conductance were taken in the field using Oakton $\mathrm{pH} /$ conductivity $/{ }^{\circ} \mathrm{C} 10$ series hand held meters, which were calibrated with Oakton buffers $(4.01,7.00,10.0,84 \mu \mathrm{S}$ and $447 \mu \mathrm{S})$ during every field visit. A LaMotte Alkalinity kit, Model DR-A was used in the field to titrate for alkalinity. Grab samples were collected using protocols and containers dependent on the desired analysis according to Standard Methods (Clesceri et al., 1998). Samples for dissolved calcium and magnesium concentrations were analyzed by the Santee Cooper Analytical and Biological Laboratory located in Moncks Corner, SC. A detailed description of Standard Operating Procedures is included in the TMDL Quality Assurance Project Plan and Final Draft Report (Amatya et al, 2010). Samples for Total (TSS) and Volatile (VSS) Suspended Solids were analyzed by project personnel at the USDA Forest Service Center for Forested Wetlands
Research using Standard Methods 2540 D and E (1988). Water chemistry data on TSS, VSS, $\mathrm{pH}$, specific conductance, and alkalinity were statistically analyzed for their means and distributions and plotted using a program in MATLAB software (Mathworks, 2009). The Tukey's test for significant difference in multiple mean concentrations of each of the parameters between the locations was used at $\alpha=0.05$ level using a standard error bar representing 95\% confidence intervals.

Samples collected for stable isotope $\left(\delta^{18} \mathrm{O}, \delta^{2} \mathrm{H}\right)$ analyses were filtered and stored away from light in glass vials with no head space. Analysis was performed with a Picarro L2120-i high-precision isotopic water analyzer, using Cavity Ring-Down Spectroscopy (CRDS), in the Department of Geography at Nipissing University, Ontario, Canada. Sample precision (maximum standard deviation of all injected samples) for $\delta^{18} \mathrm{O}$ and $\delta \mathrm{D}$ was $\leq 0.12 \%$ and $\leq 0.26 \%$, respectively. Accuracy (average deviation from true value or 'Big Delta') for $\delta^{18} \mathrm{O}$ and $\delta \mathrm{D}$ was $\leq 0.24 \%$ ond $\leq 0.81 \%$, respectively. Accuracy was evaluated using secondary lab standards and IAEA standard VSMOW2. Samples were tested for chemical contamination with potential to affect CRDS results using Picarro's ChemCorrect ${ }^{\mathrm{TM}}$ software.

\section{RESUlTS}

\section{A. Hydrological and Dye Trace Data}

The impact of fluctuating lake levels on the limestone aquifer, as observed at CS, is shown in Figure 3. The daily maximum elevation of $C S$ had an overall trend that matched the rise and fall of Lake Marion daily maximum elevation in 2009.

Two qualitative dye tracing events were conducted at SS during low and high flow conditions. Approximate arrival of dye at CS was observed using visual inspection only. The red dye injected at SS on August 28, 2008 was expected, but not observed, at CS, even though depth of water at the SS location was $0.19 \mathrm{~m}$, with an average velocity of $0.73 \mathrm{~m} / \mathrm{s}(2.4 \mathrm{ft} / \mathrm{sec})$. It was hypothesized that the organics present in the surface stream at SS could be interfering with the red dye tracer. A second tracer was injected using green dye at SS on April 2, 2009, a wet antecedent condition. This time, the dye arrived at CS in 15 minutes. The depth and velocity at SS were not measured, but the depth was noticeably greater and flow volume much higher on April 2, 2009 than on the previous tracer date on August 28, 2008, a relatively dry period. Another tracer test conducted on August 28, 2008 resulted in the green dye taking 18 minutes to arrive from $\mathrm{GW}$ to CS, and dye at this location was not repeated on the April 2, 2009 trace.

\section{B. Geochemical Data}

Tukey's multiple means testing for geochemical data (Fig. 4) showed significant $(\alpha=0.05)$ differences in TSS 


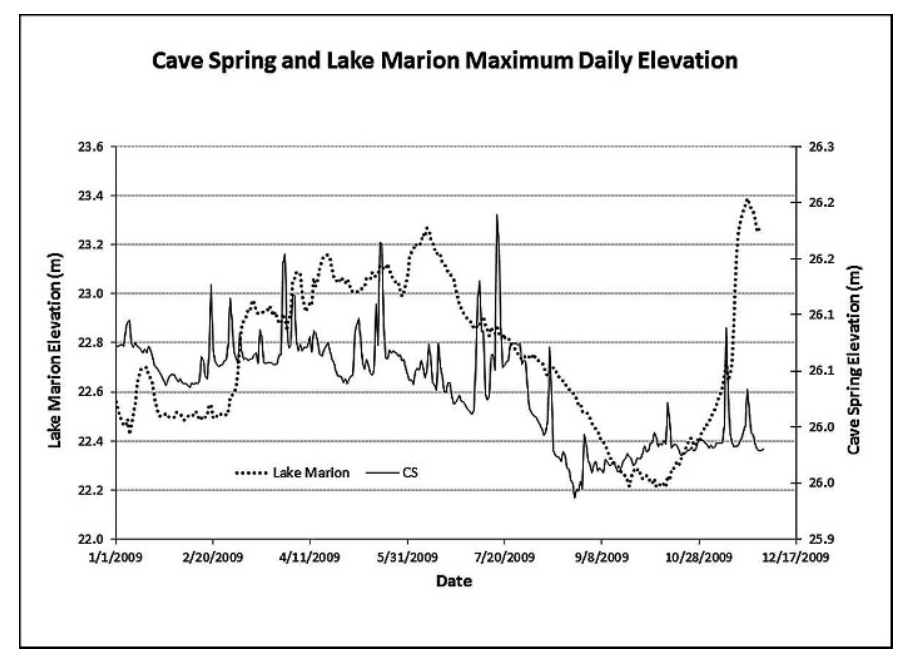

Figure 3. Daily maximum elevations of CS and Lake Marion (proxy for CBC) demonstrate a relationship of increasing and decreasing elevation in tandem (elevation scales on separate axes and vary by a factor of 4 ).

and VSS between locations SS, CS, and GW. The highest values were measured at $\mathrm{SS}$, which varied based on surface water conditions and averaged $5.0 \mathrm{mg} / \mathrm{L}$ for TSS and $1.5 \mathrm{mg} / \mathrm{L}$ for VSS. Significantly $(\alpha=0.05)$ lower values were measured at GW and CS. CS had an average TSS value of $0.5 \mathrm{mg} / \mathrm{L}$ and an average VSS value of $0.2 \mathrm{mg} / \mathrm{L}$. GW had an average TSS value of $0.3 \mathrm{mg} / \mathrm{L}$ and an average VSS value of $0.1 \mathrm{mg} / \mathrm{L}$. The high TSS and VSS values at GW measured on the day of a sinkhole collapse in the suspected upstream portion of the conduit were not included in the averages. The extremely high TSS and VSS values were 18.6 and $2.5 \mathrm{mg} / \mathrm{L}$, respectively, a $6100 \%$ and $2400 \%$ increase in the average values.

Significant differences $(\alpha=0.05)$ were also found between the sampling locations for dissolved calcium. The measurements at SPS were significantly higher than GW and CS, which, in turn, were significantly higher than SS. The average dissolved calcium value at SPS was $85.1 \mathrm{mg} / \mathrm{L}$. The average value was $53.3 \mathrm{mg} / \mathrm{L}$ for $\mathrm{GW}, 46.1 \mathrm{mg} / \mathrm{L}$ for $\mathrm{CS}$, and $23.7 \mathrm{mg} / \mathrm{L}$ for SS. The lowest measured value $(15.6 \mathrm{mg} / \mathrm{L})$ at $\mathrm{SS}$ was $83 \%$ lower than the highest measured value $(91.7 \mathrm{mg} / \mathrm{L})$ at $\mathrm{SPS}$.

Significant differences $(\alpha=0.05)$ for alkalinity were also observed between the sampling locations. The measurements at SPS were significantly higher than at $\mathrm{GW}$ and CS, which, in turn, were significantly higher than at the SS. The average alkalinity value at SPS was $221.3 \mathrm{ppm}$. The average value was $146.7 \mathrm{ppm}$ for $\mathrm{GW}$, $131.8 \mathrm{ppm}$ for $\mathrm{CS}$, and $61.2 \mathrm{ppm}$ for SS. The lowest
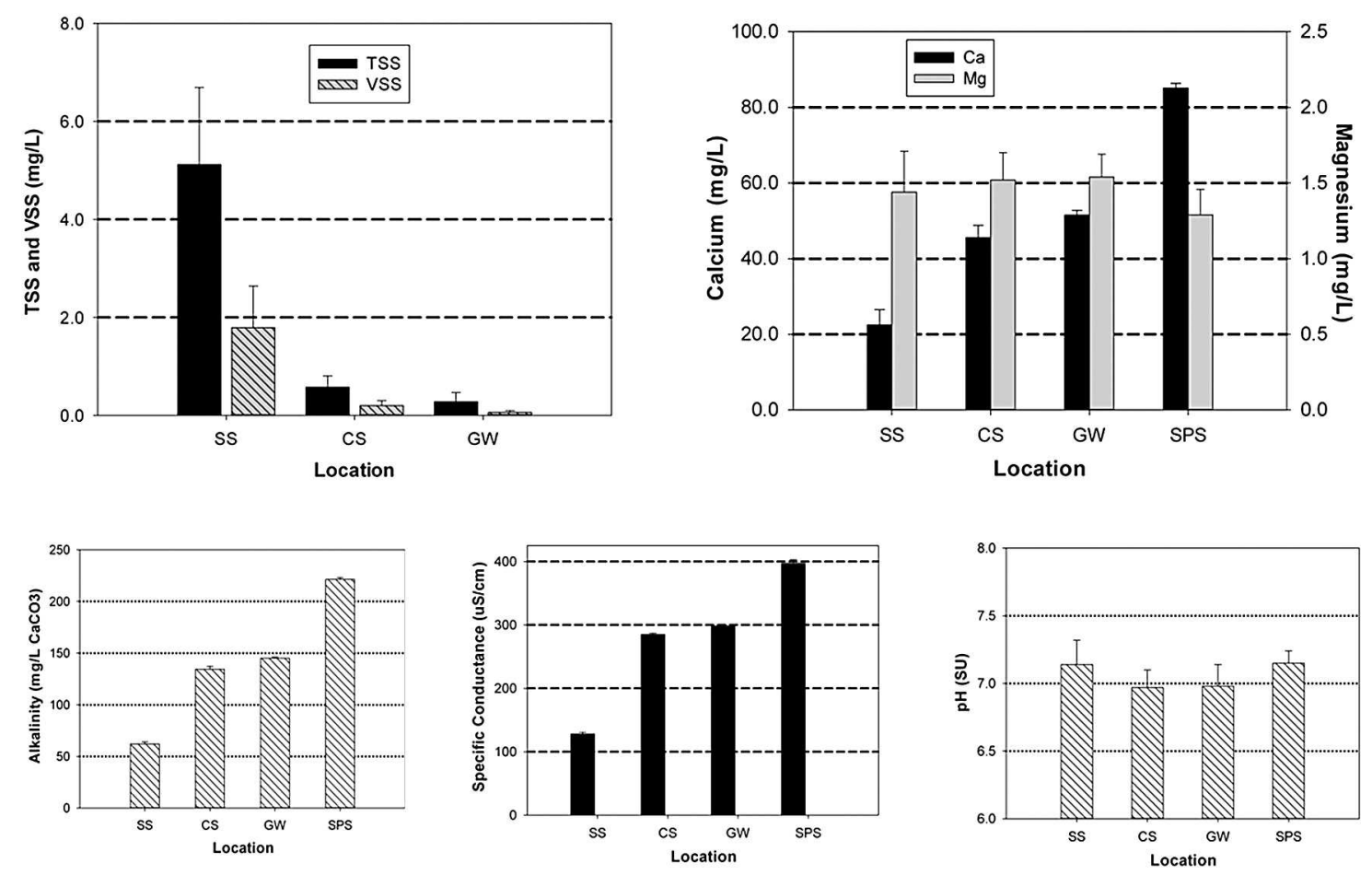

Figure 4. Mean water quality data and $95 \%$ confidence interval shown by vertical bar for (a) total suspended solids (TSS) and volatile suspended solids (VSS) $(n=12$, no samples from SPS), (b) dissolved calcium and magnesium ions $(\mathrm{n}=15$ except at SPS where $n=5$, and SS where $n=14)$, (c) specific conductance $(n=24$ except SPS where $n=5)$ for the designated locations (Fig. 1), (d) alkalinity, and (e) pH (both have $n=19$ except for SPS where $n=3$ ). SPS was sampled less often due to low flow volume at location, likely due to drought during sampling period. GW and SS flow combine together right before discharging at CS; SPS is separate from the Santee Cave system. 
Flow characterization in the Santee Cave system in the Chapel Branch Creek watershed, upper coastal plain of South Carolina, USA

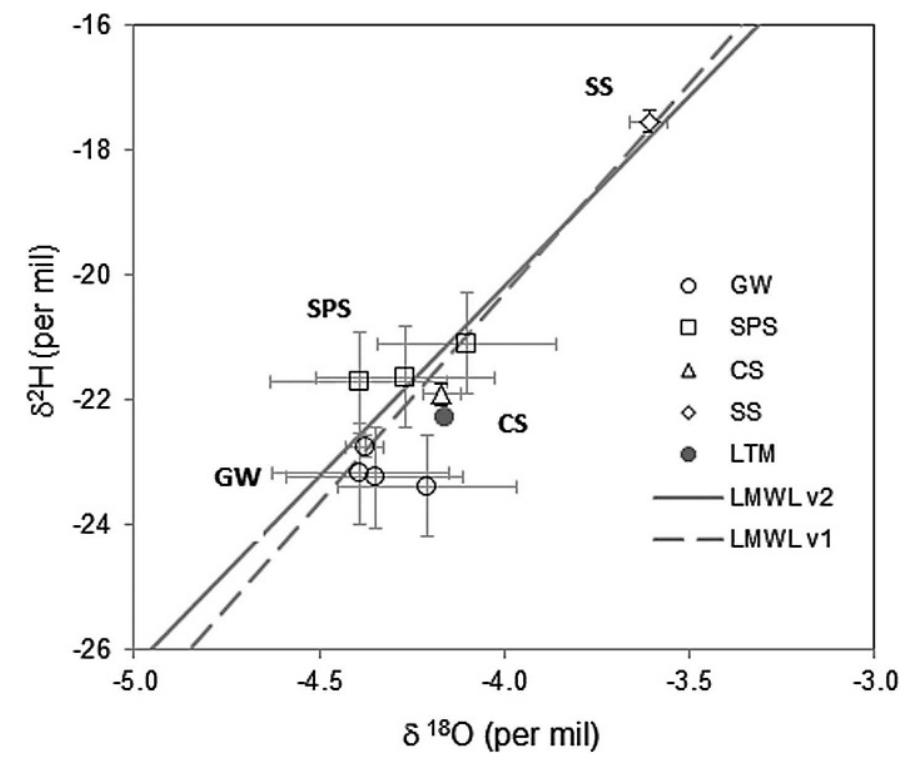

Figure 5. Stable isotope signatures of SS, CS, SPS, and GW from Mar-09 and Aug-09 sampling events. LMWL for the Cape Hatteras GNIP station (includes two versions of regression fit) and the long-term weighted mean precipitation signature (LTM) are also included.

measured value $(46.0 \mathrm{ppm})$ at $\mathrm{SS}$ was $81 \%$ lower than the highest measured value $(236.0 \mathrm{ppm})$ at SPS.

Significant differences $(\alpha=0.05)$ were also found between the sampling locations for specific conductance. The measurements at SPS were significantly higher than GW and CS, which, in turn, were significantly higher than at SS. The average specific conductance value at SPS was $397.2 \mu \mathrm{S}$. The average value was $292.8 \mu \mathrm{S}$ for $\mathrm{GW}, 274.7 \mu \mathrm{S}$ for $\mathrm{CS}$, and $129.3 \mu \mathrm{S}$ for $\mathrm{SS}$. The lowest measured value $(104.7 \mu \mathrm{S})$ at SS was $76 \%$ lower than the highest measured value $(445.0 \mu \mathrm{S})$ at SPS.

Dissolved magnesium and $\mathrm{pH}$ values show little variation between the four locations SS, GW, CS, and SPS, as indicated in difference of means testing in Figure 4. Values for dissolved magnesium were similar between sites and ranged from $1.2-1.8 \mathrm{mg} / \mathrm{L}$ with a mean concentration of $1.5 \mathrm{mg} / \mathrm{L}$ at all locations except SPS, which had a mean concentration of $1.3 \mathrm{mg} / \mathrm{L}$ (Figure 4). The $\mathrm{pH}$ values ranged from 6.6-7.6 SU with means of 7.1, 7.0, 6.9, and 7.2 at SS, CS, GW, and SPS, respectively (Fig. 4).

\section{Stable Isotope Analyses}

Stable isotopes of water (Fig. 5) plot along the Cape Hatteras Local Meteoric Water Line (LMWL), used here to approximate the range of signatures for precipitation in the $\mathrm{CBC}$ watershed region; this data is available through the IAEA's Global Network of Isotopes in Precipitation (GNIP) program and includes two different versions of line regression fits (IAEA/WMO, 2006). The long-term weighted mean isotopic signature of precipitation from the Cape Hatteras GNIP station is also included in this figure.
Spring waters (SPS), GW and CS plot significantly more negative (depleted of the heavier isotopes) and closer together than SS. They also plot closer to the long-term weighted mean precipitation signature, expected for groundwater recharged by contemporary precipitation. GW plots more negative than SPS, suggesting that SPS, with less updip aquifer area, may be slightly more influenced by surface recharge. This also appears consistent with earlier reference to Stone (pers. comm., 2009) where GW has been shown to be a combination of recharge and old water.

On 3-18-09, samples from all three locations (GW, CS and SS) were collected during baseflow conditions 2 days after a 25-30 mm rain event. Using a simple linear mixing model approach (e.g. Sklash and Farvolden, 1979), with contributing end-members of $\mathrm{GW}\left(\delta^{18} \mathrm{O}\right.$ of $-4.38 \%$ ) and $\mathrm{SS}\left(\delta^{18} \mathrm{O}\right.$ of $-3.61 \%$ ), diffuse groundwater contributions to $\mathrm{CS}\left(\delta^{18} \mathrm{O}\right.$ of $-4.17 \%$ ) are estimated to be $73 \%$ of discharge, with $23 \%$ derived from upstream surface water SS.

\section{Discussion}

Results from this study indicate that the flow at CS and the spring seeps was recharged predominantly from diffuse flow from the matrix, with a slow response of surface water infiltration to the conduit. The term "slow" is relative. In this study, "slow" implies that surface water did not respond with immediate (storm event) movement from the surface, into the aquifer matrix, and then discharged from spring seeps in the $\mathrm{CBC}$ watershed.

Springs dominated by diffuse flow with slow surface water recharge have fewer variations in flow than springs dominated by conduit flow. Data analysis from Williams et al. (2012) indicated that hydrograph peaks at CS were not from GW baseflow but mainly SS inputs from surface water runoff during rain events. Independent stable isotope analysis additionally suggested that discharge at CS is dominated by diffuse flow from the aquifer matrix (slow moving water), contributed heavily from the GW conduit. A linear mixing model using $\delta^{18} \mathrm{O}$ and assuming contributing end-members of GW and SS estimated diffuse groundwater contributions to CS to be $73 \% \mathrm{GW}$ and $23 \% \mathrm{SS}$.

The TSS and VSS measurements also substantiated the claim of a dominant GW contribution from diffuse flow to CS. TSS and VSS values at GW during the study period were consistently small values and had a small standard deviation. This was likely due to sinkholes in the upbasin of the surface watershed routinely displaying no obvious direct openings to the karst below. The only anomalously large TSS and VSS values occurred after a sinkhole collapse in a suspected upstream portion of the conduit serving GW (Edwards and Amatya, 2010). The otherwise low TSS and VSS values indicated a typically slow arrival time from surface to groundwater inputs to GW. The TSS and VSS values at CS had only slightly larger average than 
$\mathrm{GW}$, but significantly smaller average than SS, indicating the dominant flow to CS during baseflow was clearly from GW and not SS. The average TSS and VSS values were significantly larger at SS than either GW or CS, and likely contributed to the slight increase of TSS and VSS values at CS.

Alkalinity measurements also substantiated this claim of a dominant GW contribution from diffuse flow to CS. The alkalinity measurement at GW during the April 2, 2009 storm event was $148.0 \mathrm{ppm}$, very close to the $146.7 \mathrm{ppm}$ (5.0 ppm standard deviation) average measurement at that location. During the same storm event, the alkalinity measurement at CS was $70 \mathrm{ppm}$, almost half as much than the average measurement of $131.8 \mathrm{ppm}$ (20.4 ppm standard deviation) at that location. The minimal change in average value, with a small standard deviation, at GW during a storm event indicated diffuse flow. The flow at CS showed a significant decrease in alkalinity. The CS flow was likely diluted with the surface waters of significantly lower alkalinity from SS (average alkalinity of $61.2 \mathrm{ppm}$ with a 6.4 standard deviation).

The alkalinity, dissolved calcium and specific conductance measurements from the four sampling locations SS, $\mathrm{CS}, \mathrm{GW}$, and SPS all represented varying degrees of diffuse flow and surface-groundwater connections in the Santee Limestone matrix in the $\mathrm{CBC}$ watershed. The sampling location SPS, with the highest of these measurements, represented the discharge with the longest residence time in the aquifer; and therefore, longest contact with the bedrock and slowest flow. The seeps were not hydrologically connected to the Santee Cave system. More likely, these seeps were impacted by the fluctuating $\mathrm{CBC}$ and Lake Marion water elevation, as depicted in Figure 3 (discussed below). The conduit serving Santee Cave at GW and CS had significantly lower alkalinity, specific conductance, and dissolved calcium than SPS, indicating shorter residence time of water in the aquifer; and therefore, faster through or conduit flow than SPS. GW had similar, but slightly larger, alkalinity concentrations than CS due to the contribution to CS from not only the predominant CS baseflow component of GW, but also SS baseflow and stormflow components to CS. The lowest values, as expected, were measured at the surface waters of a disappearing stream at SS. The difference in the chemistry in spring seeps and GW could be due to several factors. The noticeably larger conduit size at GW could move water faster through the aquifer to reduce contact time with the limestone. The groundwater conduit feeding GW also had a larger surface watershed recharge area with sinkholes that may allow for quicker infiltration of water into the matrix and to the conduit. Once in the matrix, the aquifer recharge could flow diffusely over a larger area for GW than SPS, until it reached the GW conduit. The seeps were also higher in elevation within the Santee Limestone unit, giving them potentially less volume of the aquifer matrix above to yield a discharge.
The stage elevation at CS and adjacent Lake Marion (equal to the elevation of the flooded portion of $\mathrm{CBC}$ ) also indicated a relation between fluctuating base level of $\mathrm{CBC}$ and discharge of the Santee Limestone karst aquifer at CS. If we ignore the peaks in Figure 3, which were surface water contributed from SL7, the baseflow stage elevation at the spring broadly increased and decreased with the changing lake levels. If the surface-groundwater connections in GW were quick, one would not expect the broad several month long correspondences, but rather would expect rapid changes into the conduit that serves $\mathrm{GW}$ and CS. The correspondence suggested the GW source reflected a rainfall response at a rate more similar to the large reservoir. Geochemical data also indicated a slow surfacegroundwater connection typical for GW and CS (minus the stormflow contributions from SS), and the hydrologic data in Figure 3 were collected during drought years, as indicated from measured precipitation compared to longterm precipitation records (Williams et al., 2012).

These results suggested that during low lake levels, such as at the time of first dye trace, the water table in the limestone might be low and the surface water going into SS infiltrates downward into the empty conduits. The water may then either be stored until the water table increases or perhaps continues draining to $\mathrm{CBC}$ through the aquifer at a lower elevation than the cave stream passage, which was hypothesized earlier by Amatya et al. (2011). For the first dye trace, when no dye was observed from SS to CS, the average lake level on August 28, 2008 was 21.79 meters (71.49 feet) (USGS, 2009). The average lake level on April 2, 2009, when the dye took only 15 minutes to reach CS, was $22.96 \mathrm{~m}$ (75.34 feet) (USGS, 2009). Thus, a $1.17 \mathrm{~m}$ (3.85 foot) fluctuation in lake level showed an impact on the water table in the limestone aquifer and cave stream. As lake levels decrease, the aquifer may empty at lower elevation springs and more surface water in the basin is lost to groundwater, as was also argued by Amatya et al. (2011).

The trace conducted on August 28, 2008 resulted in the green dye taking 18 minutes to arrive from GW to CS. The conduit from GW to CS can be mostly traversed and there was no indication of loss to a lower conduit. In fact, conduit baseflow discharge at GW and CS was witnessed on weekly field visits during 2009 as always continuous and steady. Because 2007-08 were drought years, the Santee Limestone in this region appeared to have significant storage capacity, characteristic of diffuse flow, to maintain steady flow at the spring after a two-year drought. Even though GW may result from flow in multiple conduits from an unknown upstream area, the recharge was likely more diffuse than direct recharge from surface water and precipitation. A conceptual model for groundwater flow in the $\mathrm{CBC}$ watershed is shown in Figure 6.

The lack of significant difference between the locations for $\mathrm{pH}$ parameter indicated a limited value for measuring these individual parameters to identify flow type and 
Flow characterization in the Santee Cave system in the Chapel Branch Creek watershed, upper coastal plain of South CARolina, USA

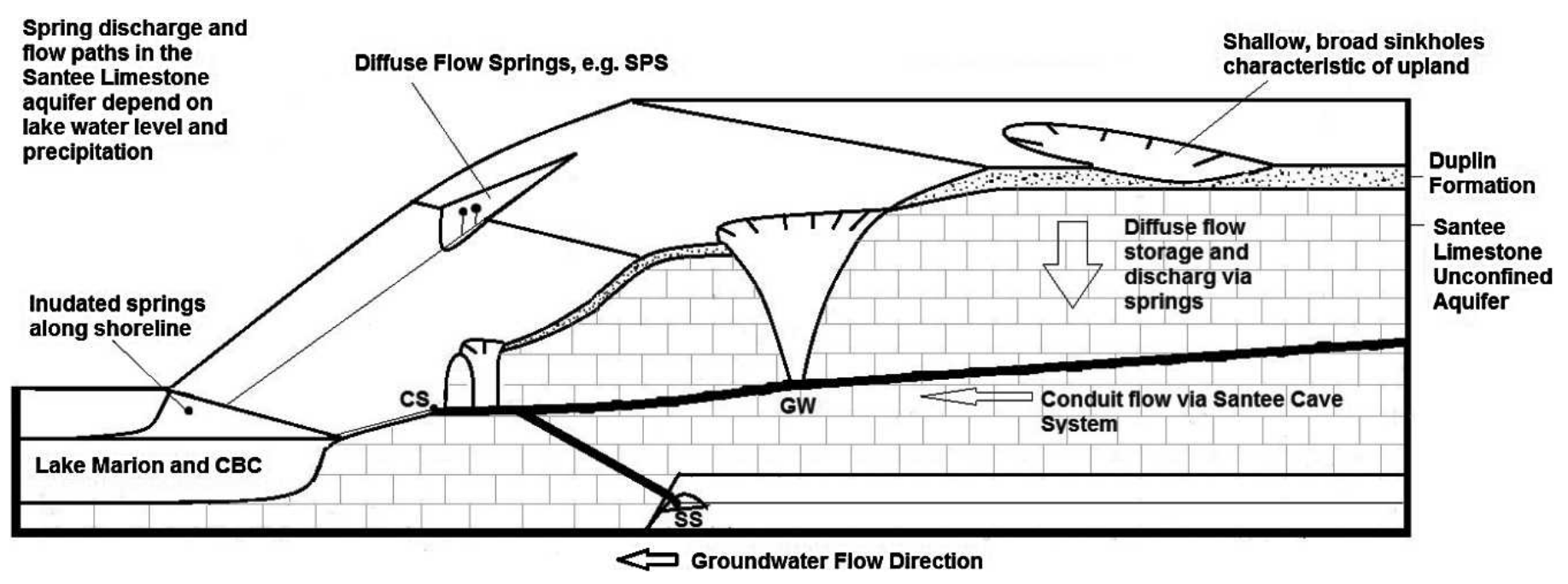

Figure 6. Conceptual model of groundwater flow (diffuse and conduit) between Santee Limestone karst aquifer and Chapel Branch Creek discharging to Lake Marion.

surface-groundwater connections in this particular watershed. However, the comparison between variable dissolved calcium and non-variable dissolved magnesium between locations provided insight into karst subsurface flow dynamics given the contact time with limestone.

\section{Conclusions}

The analysis of hydrologic, geochemical and stable isotopic data collected within the Chapel Branch Creek watershed in 2009 confirmed the first hypothesis that the discharge via CS from the Santee Limestone to CBC is predominantly recharged by a diffuse flow component from the matrix with slow surface-groundwater connection. The Santee Limestone in the upper Floridan aquifer, therefore, behaves like the karst in the lower Floridan aquifer, with the matrix (diffuse flow) contributing heavily to aquifer discharge via conduits to springs. Analysis and interpretation of these data also confirmed the second hypothesis that the fluctuating $\mathrm{CBC}$ stage elevations influence the aquifer water table at Santee Cave. Studies in the Floridan aquifer have likewise found hydrologic connections between the surface water in lakes and groundwater levels (Lee, 2000; Watson et al., 2001; Lin, 2011).

Characterizing the hydrology of the Chapel Branch Creek watershed is essential for water resource protection. This reservoir-like embayment has been on the EPA 303(d) list for impaired water bodies for several years, and both point and non-point sources of water pollution are abundant in this multiple land-use watershed. Further studies to elucidate surface-groundwater connections and water quality at the springs along $\mathrm{CBC}$ would help with future Best Management Practices for Chapel Branch Creek and the greater karst region.

\section{ACKNOWLEGEMENTS}

This study was made possible by the support from South Carolina Department of Health and Environmental Control's 319 Grant Agreement \#EQ-7-514 (Project \#4OFY06) with US Forest Service Center for Forest Wetlands Research (SRS 06-CO-11330135-122). The authors acknowledge the following for assistance in this particular study: Irvin Pitts and Valerie Carter-Stone with SC DNR for permit to access Santee Cave; Field help from FS technicians Andy Harrison and Matt Kaswaski; Water sample analysis from Larry McCord, Brian Lynch, Chip Davis, Anita Brown, Linda Williams and Debra Guerry from Santee Cooper Biological \& Analytical Laboratory; weyerhaeuser company Cooperation from Mayor Silas Seabrooks and Herman Keller with the Town of Santee and Gary Bennett with Santee National Golf Course; Rangers Nathan Maiwald and Adin Fell with Santee State Park; SC DHEC Hydrologist Pete Stone; SC DHEC Andy Miller, Meredith Murphy, Matt Carswell, and Nydia Burdick; SCDNR Jim Scurry, and NPS Denver Ingram. Thanks also to Dr. Herbert Ssegane at University of Georgia for assistance with statistical analysis of the water quality data. And special thanks to the residents of Chapel Branch II for their boundless energy and local support. Financial support for stable isotope analyses were provided by the Canada Foundation of Innovation, the Canada Research Chair Program and Nipissing University, ON, Canada. Thanks to Dr. Krys Chutko for technical support on isotope analyses. Cape Hatteras GNIP station data were accessed through the International Atomic Energy Agency's GNIP program with analytical support from the University of Copenhagen and the USGS Reston Stable Isotope Laboratory. 


\section{REFERENCES}

Amatya, D.M., Manoj, J., Edwards, A.E., Williams, T.M., and Hitchcock, D.R., 2011, SWAT- based streamflow and embayment modeling of karst affected Chapel Branch watershed, SC: Transactions of American Society of Agricultural and Biological Engineers, v. 54, no. 4, p. 1311-1323.

Amatya, D.M., Williams, T.M., Edwards, A.E., and Hitchcock, D.R., 2010, Final Draft Report and Appendices A, B, C, and D on "Total Maximum Daily Load (TMDL) Development for Phosphorus, Chapel Branch Creek (SC014)" submitted to SC Department of Health \& Environmental Control, Bureau of Water, Division of Water Quality, Columbia, SC April 2010.

Ashton, K., 1966, The analysis of flow data from karst drainage systems: Transaction of Cave Research Group, Great Britain, v. 7, p. 161-203.

Atkinson, T.C., 1977, Diffuse flow and conduit flow in limestone terrain in Mendip Hills, Somerset (Great Britain): Journal of Hydrology, v. 35 , p. $93-100$

Clesceri, L.S., Greenberg, A.E., and Eaton, A.D., eds., 1998, Standard Methods for the Examination of Water and Wastewater, $20^{\text {th }}$ Edition, Washington, DC, American Public Health Association.

Criss, R.E., Fernandes, S.A., and Winston, W.E., 2001, Isotopic, geochemical and biological tracing of the source of an impacted karst spring, Weldon Spring, Missouri: Environmental Forensics, v. 2, p. $99-103$.

Edwards, A.E., and Amatya, D.M., 2010, Sinkhole collapse in Santee, South Carolina: Photo Essay: South Carolina Geology, v. 47, p. 17-18.

Edwards, A.E., and Amatya, D.M., 2009, Evaluating forested karst topography with LiDAR: USDA Forest Service Beneath the Forest Fall 2009 Newsletter; Accessed on web at: http://fsweb.wo.fs.fed.us/ $\mathrm{mgm} / \mathrm{geology}$ _notebook.html.

ERC, 1999, Drainage analysis of SCDHEC dam \#D-3746 (lower Santee Shores dam), Santee, South Carolina, Orangeburg, S.C.: Engineering Resources Corporation.

Fiorillo, F., 2009, Spring hydrographs as indicators of droughts in a karst environment: Journal of Hydrology, v. 373, p. 290-301.

Florea, L.J., and Vacher, H.L., 2006, Springflow hydrographs: eogenetic vs telogenetic karst: Ground Water, v. 44, no. 3, p. 352-361.

Gunn, J., 1986, A conceptual model for conduit flow dominated karst aquifers in Gunay, G., and Johnson, A.I., eds., Proc. Ankara Symposium, "Karst water resources", July 1985, IAHS Publication, v. 161, p. $587-596$.

Hockensmith, B.L., 2009, Potentiometric map of the Floridan aquifer and tertiary sand aquifer in South Carolina - 2004: South Carolina Department of Natural Resources Water Resources Report 48.

Holler, C. Jr., 2000, Caves of South Carolina: Old Fort, North Carolina, Hollow Hills, $91 \mathrm{p}$.

IAEA/WMO, 2006, Global Network of Isotopes in Precipitation. The GNIP Database. Accessible at: http://www.iaea.org/water.

Jacobson, D.A., and Langmuir, D., 1974, Controls on the quality variations of some carbonate spring waters: Journal of Hydrology, v. 23 , p. $247-265$.

Jakucs, L., 1959, Neue methoden der hohlenforschung in Ungarn und ihre Ergebnisse: Die Hohle, v. 10, no. 4, p. 88-98.

Katz, B.G., 2004, Sources of nitrate contamination and age of water in large karstic springs of Florida: Environmental Geology, v. 46, p. $689-706$.

Katz, B.G., Coplen, T.B., Bullen, T.D., and Davis, J.H., 1997, Use of chemical and isotopic tracers to characterize the interactions between ground water and surface water in mantled karst: Ground Water, v. 35 , no. 6 , p. $1014-1028$

Lee, T.M., 2000, Effects of nearshore recharge on groundwater interactions with a lake in mantled karst terrain: Water Resources Research, v. 36, no. 8, p. 2167-2182.

Lin, Z., 2011, Estimating water budgets and vertical leakages for karst lakes in north-central Florida (United States) via hydrological modeling: Journal of the American Water Resources Association, v. 47 , no. 2, p. 287-302.

Mahler, B.J., and Lynch, L., 1999, Muddy waters: temporal variation in sediment discharging from a karst spring: Journal of Hydrology, v. 214 , p. $165-178$.
Martin, J.B., and Gordon, S.L., 2000, Surface and ground water mixing, flow paths, and temporal variations in chemical compositions of karst springs, in Sasowsky, I.D., and Wicks, C.M., eds., Groundwater Flow and Contaminant Transport in Carbonate Aquifers, A.A. Balkema, Rotterdam, Netherlands, p. 5-92.

Martin, J.B., and Dean, R.W., 2001, Exchange of water between conduits and matrix in the Floridan aquifer: Chemical Geology, v. 179, p. $145-165$.

Massei, N., Lacroix, M., Wang, H.W., Mahler, B.J., and Dupont, J.P., 2002, Transport of suspended solids from a karstic to an alluvial aquifer: the role of the karst/alluvium interface: Journal of Hydrology, v. 206 , p. $88-101$.

Mathworks, Inc., 2009, MATLAB Software version R2009b, Natick, MA, USA.

Moore, P.J., Martin, J.B., and Screaton, E.J., 2009, Geochemical and statistical evidence of recharge, mixing, and controls on spring discharge in an eogenetic karst aquifer: Journal of Hydrology, v. 376 , p. $443-455$.

Plummer, L.N., Busenberg, E., McConnell, J.B., Drenkard, S., Schlosser, P., and Michel, R.L., 1998, Flow of river water into a karstic limestone aquifer. 1. Tracing the young fraction in groundwater mixtures in the Upper Floridan Aquifer near Valdosta, Georgia: Applied Geochemistry, v. 13, no. 8, p. 995-1015.

Quinlan, J.F., and Ray, J.A., 1995, Normalized base-flow discharge of groundwater basins: A useful parameter for estimating recharge area of springs and for recognizing drainage nomalies in karst terranes, in Beck, B.F., ed., Karst geohazards, Rotterdam, A.A. Balkema, p. $149-164$.

Ritorto, M., Screaton, E.J., Martin, J.B., and Moore, P.J., 2009, Relative importance and chemical effects of diffuse and focused recharge in an eogenetic karst aquifer: an example from the unconfined upper Floridan aquifer, USA: Hydrogeology Journal, v. 17, p. 1687-1698.

SCS, 1988, Soil Survey Report of Orangeburg County, SC, State Conservationist Office, Columbia, SC.

Shuster, E.T., and White, W.B., 1971, Seasonal fluctuations in the chemistry of limestone springs: a possible means for characterizing carbonate aquifers: Journal of Hydrology, v. 14, p. 93-128.

Sklash, M.G., and Farvolden, R.N., 1979, The role of groundwater in storm runoff: Journal of Hydrology, v. 43, p. 45-65.

Stone, P., 2009, Personal Communication, Hydrologist, SC Department of Natural Resources.

USGS, 2009, Lake Levels at Elloree, SC. Reston, VA: U. S. Geological Survey.

Vesper, D.J., and White, W.B., 2004, Storm pulse chemographs of saturation index and carbon dioxide pressure: implications for shifting recharge sources during storm events in the karst aquifer at Fort Campbell, Kentucky/Tennessee, USA: Hydrogeology Journal, v. 12, no. 2, p. $135-143$.

Watson, B.J., Motz, L.H., and Annable, M.D., 2001, Water budget and vertical conductance for Magnolia Lake: Journal of Hydrologic Engineering, v. 6, no. 3, p. 208-216.

White, W.B., 2003, Conceptual models for karstic aquifers, Karst Modeling, Special Publication 5, The Karst Waters Institute, p. 11-16.

White, W.B., 1988, Geomorphology and Hydrology of Karst terrains, New York, Oxford University Press, $464 \mathrm{p}$.

Willoughby, R.H., 2002, Geologic Map of the Saint Paul Quadrangle, Calhoun, Clarendon, and Orangeburg Counties, South Carolina: S.C. Geologic Quadrangle Map GQM-08, scale 1:24 000, 1 sheet.

Williams, T.M., Amatya, D.M., Hitchcock, D.R., and Edwards, A.E., 2013, Streamflow and nutrients from a karst watershed with a downstream embayment: Chapel Branch Creek, Journal of Hydrological Engineering, in press.

Williams, T.M., 2009, Personal communication, Professor of Forest Hydrology, Clemson University.

Worthington, S.R.H., Davies, G.J., and Ford, D.C., 2000, Matrix, fracture and channel components of storage and flow in a paleozoic limestone aquifer, in Wicks, C.M., and Sasowsky, I.D., eds., Groundwater flow and contaminant transport in carbonate aquifers: Rotterdam, Balkema, p. 113-128. 